\title{
Zinc Finger Protein 292
}

National Cancer Institute

\section{Source}

National Cancer Institute. Zinc Finger Protein 292. NCI Thesaurus. Code C142228.

Zinc finger protein 292 (2723 aa, $305 \mathrm{kDa}$ ) is encoded by the human ZNF292 gene. This protein plays a role in the regulation of gene expression. 